\title{
Research on Pricing Actualization Mechanism of Residential Property Management Fee Based on Recessive Monopolization
}

\author{
Qingqiu CHEN, Jiajia TANG \\ School of Economics and Commerce, South China University of Technology, Guangzhou, China \\ chenqq2001@163.com,tjj1016@sina.com
}

\begin{abstract}
The Residential property management sector plays an increasing vital role in people's living in China, and its pricing issue should be focus of social attention. From the perspective of welfare economics and complementary goods two-part pricing, this paper examines whether there is recessive monopolization phenomenon in the residential property management fee pricing .After comprehensively studying on conditions and processes of the pricing mechanism ,the paper finds some conclusion as follows:1)the stable cooperative relationship between property management componies and real estate developers contributes the recessive monopoly power;2)the owners with seldom information and large switching cost, are locked in successive consumption process .
\end{abstract}

Index Terms - Property Management Fee, Two-part Pricing, Recessive Monopolization

\section{Introduction}

The prosperity and development of the property management services industry has brought a new way of life for urban residents, on the other hand, it also brings about a variety of complex issues, which concern the major economic and social development. Therefore, how to optimize the property management fee pricing to become the focus.

Related research from various countries differ, owing to different economic conditions, and level of property management industry. As a developing country, China's real estate and property management industry is lagging behind,the pricing of property management fee is rarely explored.

The main contribution of this paper is to show how to achieve the recessive monopoly under pricing actualization mechanism .We find that to take advantage of recessive monopolization, the companies unilaterally raise the fee, deprive welfare surplus of the owners, to achieve the purpose of long-term huge profits.

The rest is organized as follows. Section 2 reviews the two-part pricing background in existing literature. The process and conditions of the recessive monolization in pricing will be shown in Section 3 . Section 4 are some conclusions.

\section{Background on recessive monolization under two-part pricing: A Review}

Numerous studies focus on residential property management in literature, based on the study of property management practices, in the United Kingdom, the United States, Japan, Singapore and Hong Kong. While researches mainly focus on subjects as setting of the company, their operating behavior, early intervention, and the service quality so on ,this paper will explore the service fee pricing by applying a two-part pricing approach which is rarely referred to.

A good many researchers have provided professional insights into two-part pricing, which inspire further research and application. W.A.Lewis (1941) points out that the essence of the two pricing: the cost of one part related to customer's consumption, yet the other not. He also show the basic principle of pricing theory to profit maximization.

Richard Schmalensee (1981) analyzes the complementary relationship of the two products to further theory with instance of the cameras and film.

With a case of health club, Beth Hayes (1987), argues that monopoly structure is not requirement, and enumerate some life examples to illustrate the two-part pricing phenomenon in the competitive market.

Using game theory methods, Taeki Min(2002) examines the impact of the strategic interaction between vendors, and compares uniform pricing with two pricing policy. This is a significant methodological advance.

Xiangkang Yin (2004) also put forward about two pricing models: the Hotelling model and Logit model. As is shown in Hotelling model, the equilibrium price is equal to marginal cost, when the marginal customer demand is equal to the average demand; And in logical model, the marginal cost pricing is still valid, but manufacturers will be more profitable, with less consumer surplus.

Francis J.Mulhern and Robert P.Leone (1991) discuss the demand interdependencies and promotional pricing strategy in multi-product pricing by empirical approach. And then they find that the use of complementary goods can have a "multiplier effect".

Dennis W. Carlton and Michael Waldman (2002) note that the monopolist shift monopoly power to emerging markets in order to maintain the market share of the basic product. In particular, they point out that implementation mechanism complementary product tie-ins can be achieved through contracts or product design.

The two products two pricing research is still fragmented, but the existing literature may shed some light on further study and application. Thus, this paper will apply complementary products two-part pricing theory to analyze the recessive monopoly in property management fee pricing issues. 


\section{Owners behavior foundation: evaluation of the relative importance difference}

Since the property company selected by the developer has started to intervene early stage services before establishment of the owner committee, owners can't take full account of quality and price of property services. We define this asymmetry of complementary product relationship as difference of importance. Followings are 3 reasons causing owners to pay more attention to real estate (leading products ) other than property services (supplement products).

1) There are several relationship between real estate and property services, such as cause-effect, dominant-subordinate and timing-order relationship, therefore, as supplementary demand for housing, demand for property services just obtains less attention.

2) Under limited rationality, demand for property services is highly of uncertain. Owners can barely predict quality and fee price of the services when they purchase house.

3) Owners come to large cost of access to propery management information, including a lot of time and effort, furthermore, information release channel is not smooth .

From above factors, the difference of importance evaluation may highly affect owners' purchase decisions. We set importance of real estate as a value of 1 , then of the property services as a value of $\theta$; the consumer surplus of two products can be expressed as A and B, respectively. Considering the complementary goods relationship , owners' basis of decision making is $\mathrm{A}+\theta^{*} \mathrm{~B}$.

\section{Owners decisions foundation: perception welfare model}

\section{A. Model assumption and establishment}

Assumption 1: $0 \leq \theta<1$, owners are not considered or not fully consider the price, consumption and other information of the property services in the decision-making.

Assumption 2: we consider this case in competitive market that the real estate is homogeneous. Owners face a downward sloping demand curve, which is fixed to the consumption of real estate, as a unit 1; the consumption of property services is variable, shown as Q2, and P1 and P2 represent the prices of the two.

Assumption 3: The consumer's budget of expenditures for constant I. Under the restrictions of expenditures budget, owners make buying decisions based on welfare level of consumer surplus maximization.

We define the owners' actual total surplus as F, F is function of the number of price and consumption, expressed as $\mathrm{F}=[(\mathrm{P} 1,1),(\mathrm{P} 2, \mathrm{Q} 2)]$, owners' consumers surplus obtained by the two product respectively as $\mathrm{S} 1(\mathrm{P} 1,1), \mathrm{S} 2(\mathrm{P} 2, \mathrm{Q} 2)$. Besides S1 and S2 are continuously derivable, and the price derivative of $\mathrm{P} 1$ and $\mathrm{P} 2$ is negative. From above settings, we have

$$
\mathrm{F}[\mathrm{P} 1(\mathrm{P} 2, \mathrm{Q} 2),]=\mathrm{S} 1(\mathrm{P} 1)+\mathrm{S} 2(\mathrm{P} 2, \mathrm{Q} 2)
$$

$\theta$ is the extent of the owners' consideration of property services information, thus basis of decision making is perception of welfare surplus:

$$
\mathrm{FF}[\mathrm{P} 1,(\mathrm{P} 2, \mathrm{Q} 2)]=\mathrm{S} 1(\mathrm{P} 1)+\theta * \mathrm{~S} 2(\mathrm{P} 2, \mathrm{Q} 2) \square \square \square
$$

From function, we can more clearly see $\theta$ at different intervals meaning different perception of the level of benefits:

When $\theta=1$, FF $[\mathrm{P} 1,(\mathrm{P} 2, \mathrm{Q} 2)]=\mathrm{S} 1(\mathrm{P} 1)+\mathrm{S} 2(\mathrm{P} 2, \mathrm{Q} 2)$.

This is the special case of an extreme rational owners, residential real estate and property services fee are fully considered in the purchase decision, namely, owners seeking the actual level of benefits to maximize, can completely anticipate future demand for property services. However this completely rational people does not exist, the paper does not consider this case.

When $\theta=0$, the perceived level of benefits become FF $[\mathrm{P} 1(\mathrm{P} 2, \mathrm{Q} 2)=\mathrm{S} 1(\mathrm{P} 1)$, which is the prevalent situation: when in purchase decision, the owners donot consider the price ,consumption and other information of property services, make perceived level of benefits fully from the purchase price of the residential real estate information.

When $0<\theta<1$, the perception of the level of benefits between former two cases, the owners partly take property services fee into account. Along with owners' purchase experience of complementary products increase, ablity to overcome the impact of the difference of relative importance evaluation improves.Thus, the higher the degree of consideration of property services information, the greater the value of $\theta$.

Above analysis, this paper, Assuming $\theta$ in the short term will not change, a longer period, the owners through the accumulation of two complementary experience in consumer goods, or by other means to obtain the understanding of vendor pricing, which in the purchase decision, Concerned about the extent of the property services price information will change, $\theta$ changes.

\section{B. Model analysis}

We discuss the purchase behaviors of residential real estate and property services in two phases.

Phase I, real estate companies adjust the prices of two products $\mathrm{P} 1$, $\mathrm{P} 2$ to $(\mathrm{P} 1+\Delta \mathrm{P} 1)$ and $(\mathrm{P} 2+\Delta \mathrm{P} 2)$, the owners learn about the price adjustment information, and then estimate future consumption and change in the perception of benefits level to decide whether to buy. The purchase decision stems from whether FF increase. Experienced owners will refer to consumption in the past and compare the similar products, while first-time buyers may estimate the volume of consumption in the future by virtue of feeling, this will be reflected in the different values of $\theta$.

Phase II, owners use and pay the residential real estate prices and property service charges. On basis of the actual consumption of property services Q2, we can evaluate actual changes in the level of benefits before and after the price adjustment. When there is a new decision-making, the owners suferring a decline in the level of benefits, will purchase less property services, which may even affect other consumer purchase choices. 
It's easy to clearly understand the owners' behavioral characteristics and the actual level of benefits for the real estate company, so they can adjust real estate prices, to provide higher perceived benefits in order to attract owners to participate in the consumption in stage I. The formula is expressed as:

$$
\Delta \mathrm{F}[\mathrm{P} 1,(\mathrm{P} 2, \mathrm{Q} 2)]=0 \text {, and } \Delta \mathrm{FF}[\mathrm{P} 1,(\mathrm{P} 2, \mathrm{Q} 2)]>0 .
$$

Combined with equation (1), the actual level of benefits adjusted becomes :

$$
\begin{aligned}
\Delta \mathrm{F}[\mathrm{P} 1,(\mathrm{P} 2, \mathrm{Q} 2)]= & {[\mathrm{S} 1(\mathrm{P} 1+\Delta \mathrm{P} 1)+\mathrm{S} 2(\mathrm{P} 2+\Delta \mathrm{P} 2, \mathrm{Q} 2)] } \\
& -[\mathrm{S} 1(\mathrm{P} 1)+\mathrm{S} 2(\mathrm{P} 2, \mathrm{Q} 2)]
\end{aligned}
$$

Then, perceived welfare function becomes:

$$
\begin{aligned}
\Delta \mathrm{FF}[\mathrm{P} 1,(\mathrm{P} 2, \mathrm{Q} 2)] & =\Delta \mathrm{F}[\mathrm{P} 1,(\mathrm{P} 2, \mathrm{Q} 2)]+(\theta-1) \\
& *[\mathrm{~S} 1(\mathrm{P} 2+\Delta \mathrm{P} 2, \mathrm{Q} 2)-\mathrm{S} 1(\mathrm{P} 2, \mathrm{Q} 2)]
\end{aligned}
$$

From above ,the principles of the real estate manufacturers to adjust prices are :

$\Delta \mathrm{F}[\mathrm{P} 1,(\mathrm{P} 2, \mathrm{Q} 2)]=0$, and $\Delta \mathrm{FF}[\mathrm{P} 1(\mathrm{P} 2, \mathrm{Q} 2)]>0$, combined with equation (4), following is:

$$
(\theta-1) *[\mathrm{~S} 1(\mathrm{P} 2+\Delta \mathrm{P} 2, \mathrm{Q} 2)-\mathrm{S} 1(\mathrm{P} 2, \mathrm{Q} 2)]>0
$$

With negative price elasticity of the welfare function and assumption of $\theta<1$, we can obtain $\Delta$ P2 $>0$.And in accordance with the actual welfare function $\Delta \mathrm{FF}=0$, we get $\Delta \quad \mathrm{P} 1<0$. From the point of welfare economics, this conclusion can explain how real estate companies improve the perception of the level of benefits of the owners by reducing P1 but appropriately increasing P2 .In other words, this price adjustment ensure the profitability of the manufacturers will not be affected, while more owners can also be attracted. Due to the presence of $\theta$, even if price adjustment reduce the actual level of benefits for owners, their perceived level of benefits may still improve.

As shown from equation (4), the smaller the value of $\theta$ is, the larger the value of $\Delta \mathrm{FF}$ is, and when $\theta$ is small to zero, which means that the price reduction of real estate directly to the perceived benefit level rise. With the actual level of benefits the same, owners ignoring property company services price information will be more attractive to involve in the purchase, meaning that the pricing strategies is effective.

\section{Property Company strategy :customer lock-in strategy}

In order to achieve customer lock-in, real estate companies will reduce the price of the house, to expand their customer base, and then charge a high price of property services in the future to gain profit. There are many reasons to explain customer lock-in: the relationship between the two complementary products, switching cost, time preference, cost of searching for information, limited information theory and so on .

In practice, property management companies and real estate companies cooperate to achieve customers lock-in for the owners, through following two steps:
1) The real estate companies take advantage of complementary goods two-part pricing strategies, apply a variety of marketing tools to attract more consumers to participate in consumer lock-in.

2) Under customer lock-in for owners, the property management companies unilaterally raise the fee, deprive welfare surplus of the owners, to achieve the purpose of longterm huge profits.

This lock-in allowing manufacturers to further add the property management fee will not be resisted by the owners, which means that existing owners can accept a certain degree moderately high pricing of the property management fees. On locked condition, there is no other property management companies matching the housing for owners. In fact, this lockin leads recessive monopoly with dual nature features of a competitive market structure and monopoly power.

\section{Conclusion}

This paper focuses on recessive monopoly issues of property management fee pricing. After summarizing the existing literature's merit and shortcoming, we apply a new approach of two-part pricing to analyze the difficult problem in the property management fee pricing. Based on the owners' behavior foundation: difference of relative importance evaluation, we establish a perception welfare model to explain owners' decisions foundation, discuss the how companies achieve customer lock to gain monopoly power.

In the customer lock-in, the real estate manufacturers will reduce the owners' bargaining, lower compatibility with other property management companies, and take advantage of monopoly power to grab the owners of consumer surplus, ignoring the interests of owners and service quality.

More work has yet to be done to empirical analyze some case. The method we apply in this paper may be of some help for further research.

\section{Acknowledgment}

At the point of finishing this paper, I'd like to express my sincere thanks to all those who have lent me hands in the course of my writing this paper.

First of all, I'd like to take this opportunity to show my sincere gratitude to property association and the relevant departments, who offered me references and information on time. Secondly, I'd like to express my gratitude to my family and friends, who always support my work. Without their help, it would be much harder for me to finish my study and this paper.

\section{References}

[1] W.Arther Lewis. The Two-part Tariff. Economica,vol 8,No 31,1941:249-270

[2] Richard Schmalensee. Monopolistic two-part pricing arrangements.[J]The Bell Journal of Economics,Autumn 1981,Vol 12:445-466

[3] BethHayes. Competition and Two-Part Tariffs.[J]The Journal of Business,Jan 1987,60,1:41-54 
[4] Taeki Min , Sang Yong Kim , Changhoon Shin , Minhi Hahn.Competitive nonlinear pricing with product differentiation.[J] International Review of Economics and Finance , 11(2002) : 155-173

[5] Xiangkang Yin.Two-part tariff competition in duopoly.[J] International Journal of Industrial Organization.22 (2004):799-820

[6] FrancisJ.Mulher \& Robert P.Leone.Implicit Price Bundling of Retail Products:A Multiproduct Approach to Maximizing Store Profitability.[J]Journal of Marketing,Oct 1991,Vol.55,No4:63-76
[7] Dennis W.Carlton,Michael Waldman. The Strategic Use of Tying to Preserve Create Market Power in Evolving Industries.[J]The Rand Journal of Economics,vol.33,No.2.,2002:194-220 